(C) Коллектив авторов, 2020

Авербах М.М., Панова Л.В., Овсянкина Е.С., Хитева А.Ю.

Роль сывороточного амилоида $\mathrm{A}$

и С-реактивного белка в прогнозировании

послеоперационных осложнений

и обострения туберкулезного процесса

после хирургического вмешательства

у детей старшего возраста и подростков

Федеральное государственное бюджетное учреждение «Центральный научно-исследовательский институт туберкулеза» Министерства науки и высшего образования, 107564, г. Москва, Российская Федерация

\title{
Резюме
}

Введение. Поиск ранних лабораторных маркеров, указывающих на развитие обострения или осложнения основного процесса у детей и подростков, оперированных по поводу туберкулеза, является актуальной проблемой.

Цель исследования - изучить изменения уровня белков острой фазы воспаления сывороточного амилоида А (САА) и С-реактивного белка (СРБ) - до операции, через 1 нед и 1-6 мес после ее проведения для раннего прогнозирования послеоперационных осложнений и обострения туберкулеза.

Материал и методы. Исследованы 28 пациентов, которым на разных сроках химиотерапии (ХT) проведены оперативные вмешательства различного объема. Сформированы 2 группы: 1-я - 22 пациента (без осложнений и прогрессирования туберкулеза), 2-я-6 пациентов (послеоперационные осложнения-4, прогрессирование туберкулеза-2). Уровни САА и СРБ изучали методом иммуноферментного анализа.

Результаты. В 1-й группе уровень САА до оперативного вмешательства составлял $13,11 \pm 0,63$ мкг/мл, во 2-й группе - 14,86 \pm 0,72 мкг/мл, эти значения достоверно не различались. Через 1 нед после операции в 1-й группе уровень САА был достоверно ниже, чем во 2-й группе (12,3 $\pm 0,57$ мкг/мл и 15,2 $\pm 0,6$ мкг/мл; $p=0,001747)$. Подобные различия сохранялись и через 1 мес $(13,57 \pm 0,46$ мкг/мл и $18,5 \pm 0,21$ мкг/мл, $p=0,0096$; соответственно). Уровень СРБ в исследованных группах имел сходную динамику. Через 1 нед и через 1 мес после операции во 2-й группе отмечен достоверный подъем уровня СРБ: $18,8 \pm 0,76$ мг/л и $14,75 \pm 1,4$ мг/л $(p=0,017581)$, и $18,6 \pm 1,1$ мг/мл и $12,8 \pm 1,73$ мг/мл $(p=0,009067)$ соответственно.

Заключение. Одновременное повышение уровней СРБ и САА на ранних сроках после операции служит прогностическим критерием послеоперационного осложнения (экссудативный плеврит) или обострения туберкулеза.

Ключевые слова: обострение туберкулеза; послеоперационные осложнения; дети; подростки; сывороточный амилоид А; С-реактивный белок

Статья поступила 21.05.2020. Принята к печати 16.06.2020.

Для цитирования: Авербах М.М., Панова Л.В., Овсянкина Е.С., Хитева А.Ю. Роль сывороточного амилоида А и С-реактивного белка в прогнозировании послеоперационных осложнений и обострения туберкулезного процесса после хирургического вмешательства у детей старшего возраста и подростков. Иммунология. 2020; 41 (4): 337-343. DOI: https://doi.org/10.33029/0206-4952-2020-41-4-337-343

Финансирование. Работа выполнена в рамках НИР № 0515-2019-0016 «Персонализированные подходы к лечению туберкулеза органов дыхания у детей и подростков».

Конфликт интересов. Авторы заявляют об отсутствии конфликта интересов. 
Averbakh M.M., Panova L.V., Ovsyankina E.S., Khiteva A.Yu.

\section{The importance of serum amyloid $A$ and C-reactive protein in predicting postoperative complications and exacerbation of tuberculosis after surgical intervention in children of older age}

Central Tuberculosis Research Institute of the Ministry of Higher Education and Science of the Russian Federation, 107564, Moscow, Russian Federation

\section{Summary}

Introduction. The search for early laboratory markers of tuberculosis progression after surgical treatment in children and adolescents is an urgent problem.

Aim. Analysis of the level of production of markers of the acute phase of inflammation serum amyloid A (SAA) and C-reactive protein (CRP) - before and after surgery in dynamics in order to predict postoperative complications and exacerbate the tuberculosis process.

Material and methods. The study was conducted on 28 patients who underwent various surgical interventions after different chemotherapy regimens. The $1^{\text {st }}$ group included 22 patients who lacked complications and progression of tuberculosis. The $2^{\text {nd }}$ group included 6 patients with postoperative signs of tuberculosis progression.

Results. SAA and CRP were examined before and one week and 1-6 months after surgery. In the $1^{\text {st }}$ group, the SAA level before surgery was $13.11 \pm 0.63 \mu \mathrm{g} / \mathrm{ml}$, in the $2^{\text {nd }}$ group $-14.86 \pm$ $0.72 \mu \mathrm{g} / \mathrm{ml}$ and had no statistical differences. After 1 week after surgery in the 1st group patients, SAA level was significantly lower than in the $2^{\text {nd }}$ group $(12.3 \pm 0.57$ and $15.2 \pm 0.6 \mu \mathrm{g} / \mathrm{ml}$, respectively, $p=0.001747)$. Similar differences occurred after 1 month $(13.57 \pm 0.46 \mu \mathrm{g} / \mathrm{ml}$ and $18.5 \pm$ $0.21 \mu \mathrm{g} / \mathrm{ml}, p=0.0096)$. The CRP level had similar dynamics. One week and one month after the operation, the $2^{\text {nd }}$ group patients had a reliable rise of the CRP level $(14.75 \pm 1.4 \mathrm{mg} / \mathrm{l}$ and $18.8 \pm$ $0.76 \mathrm{mg} / \mathrm{l}, p=0.017581$, and $12.8 \pm 1.73$ and $18.6 \pm 1.1 \mathrm{mg} / \mathrm{ml}, p=0.009067$ ), respectively.

Conclusion. The simultaneous increase of CRP and SAA levels earlier after surgery can serve as prognostic criteria for postoperative complications (exudative pleurisy) or exacerbation of tuberculosis.

Keywords: tuberculosis exacerbation; postoperative complication; children; adolescents; serum amyloid A; C-reactive protein

Received 21.05.2020. Accepted 16.06.2020.

For citation: Averbakh M.M., Panova L.V., Ovsyankina E.S., Khiteva A.Yu. The importance of serum amyloid A and Creactive protein in predicting postoperative complications and exacerbation of tuberculosis after surgical intervention in children ofolderage. Immunologiya. 2020;41 (4):337-43.DOI:https://doi.org/10.33029/0206-4952-2020-41-4-337-343 (in Russian)

Funding. The study supported by Scientific Research No. 0515-2019-0016 «Personalized Approaches to the Treatment of Respiratory Tuberculosis in Children and Adolescents».

Conflict of interests. The authors declare no conflict of interests.

\section{Введение}

В настоящее время наряду со снижением показателя заболеваемости туберкулезом детей (2018 г. - 8,3; 2017 г. 9,6 на 100000 детей) и подростков (соответственно 21,2 и 18,1 на 100000 подростков) отмечается увеличение доли больных с множественной лекарственной устойчивостью микобактерий туберкулеза (МЛУ МБТ) среди бактериовыделителей (2018 г. - 30,0 и 36,8 на 100 000, а в 2017 г. $-39,9$ и 47,5 на 100000 соответственно) [1]. В комплексном лечении этой категории пациентов значительное место занимают хирургические методы, что требует тщательного наблюдения в послеоперационном периоде. В связи с этим поиск новых лабораторных кри- териев раннего прогнозирования послеоперационных осложнений и обострения туберкулеза после хирургического вмешательства до развития рентгенологических изменений являются актуальной задачей [2].

Основными инициирующими факторами развития тканевой и системной воспалительной реакций при туберкулезе являются как антигены микобактерий, так и молекулы эндогенного происхождения, возникающие вследствие тканевого стресса в очаге инфекции, что сопровождается поступлением в системный кровоток из очага воспаления различных цитокинов и медиаторов воспаления [3]. Наиболее изученными маркерами реакций системного воспалительного ответа являются белки 
острой фазы воспаления, функции и уровни продукции большинства которых при туберкулезе достаточно хорошо изучены [4]. Уровень С-реактивного белка (СРБ) является информативным и наиболее широко используемым критерием. Уровень СРБ у больных плевритом туберкулезной этиологии в плевральной жидкости и сыворотке достаточно высок (30 мг/л и 65,5 мг/л соответственно), что значительно превышает его содержание в образцах, взятых от больных плевритом иной этиологии [5]. J. Brown и соавт. [6] исследовали содержание сывороточного СРБ в зависимости от выраженности туберкулезного процесса и наличия бактериовыделения. Уровень СРБ в случаях распространенных процессов и бактериовыделения был значительно выше, чем при ограниченных процессах без бактериовыделения - 49 мг/л (16-103 мг/л) и 19 мг/л (5-72 мг/л); $p<0,001$ [6].

Сывороточный амилоид А (САA) также является быстро и сильно реагирующим маркером острой фазы воспаления. Его динамика и функция достаточно хорошо изучены при различных формах туберкулеза [7-9]. Исследования значимости уровня продукции САА при туберкулезе у больных детей и подростков немногочисленны, и наиболее низкие показатели выявлены у детей 1-6 лет с первичным туберкулезным комплексом. У группы больных с вторичными формами туберкулеза и бактериовыделением при положительной рентгенологической динамике в легких после 3-месячного курса лечения исходные показатели САА были достоверно выше, чем у детей без бактериовыделения, и быстро снижались под влиянием химиотерапии. Наиболее высокие показатели САА отмечены в группах больных с деструктивными изменениями в легочной ткани и милиарным туберкулезом. У данной категории положительная динамика изменения концентрации САА под воздействием противотуберкулезной химиотерапии была выражена незначительно. Авторы проводили параллельное исследование концентрации СРБ у этих больных и динамика его изменения была сходна с показателями САА [10].

Г.О. Каминская и соавт. [11] также сопоставляли показатели САА и СРБ у взрослых больных активным туберкулезом. Авторы показали, что чувствительность определения САА в качестве маркера активности процесса выше, чем у СРБ, поскольку его повышенные значения обнаруживались у 99,0 \% больных, тогда как показатели СРБ в 19,3 \% случаев укладывались в пределы нормы. Степень повышения уровня САА также была гораздо выше: превышающие 100 мг/л значения содержания САА наблюдались у 68,8 \% больных, а СРБ лишь в $11,1 \%$ случаев. Степень повышения уровня САА была прямо связана с выраженностью интоксикации и массивностью бактериовыделения, видом лекарственной устойчивости МБТ, распространенностью процесса и наличием деструкции легочной ткани. Тем не менее даже у больных с ограниченными процессами, без распада и бактериовыделения, средние показатели САА группировались вокруг уровня 100 мг/л, т. е. на порядок превышали верхнюю границу нормы. Максимальные значения уровня САА у больных туберкулезом легких достигали 247 мг/л. При благоприятном эффекте лечения через 3 мес химиотерапии уровень САA снижался примерно вдвое, но оставался значительно увеличенным по отношению к норме. При неэффективном лечении он существенно не менялся.

В научной литературе мы не встретили работ, посвященных изучению динамики СРБ и САА у детей и подростков после хирургического вмешательства по поводу туберкулеза органов дыхания и их значимости для оценки развития послеоперационных осложнений и обострения заболевания.

Цель исследования - изучить изменения уровня маркеров острой фазы воспаления (САА и СРБ) до операции, через 1 нед и 1-6 мес после ее проведения для раннего прогнозирования послеоперационных осложнений и обострения туберкулеза.

\section{Материал и методы}

Проведено когортное проспективное исследование за 2018-2019 гг., в которое включены 28 пациентов. Структура клинических форм туберкулеза органов дыхания на момент планового оперативного вмешательства представлена на рисунке.

Из рисунка видно, что в структуре клинических форм туберкулеза органов дыхания преобладали туберкулемы $67,9 \%$ (из них с распадом 21,4\%), в равном проценте случаев (по 7,1) - фиброзно-кавернозный туберкулез, эмпиема плевры и «туморозная» форма туберкулеза внутригрудных лимфатических узлов (ТВГЛУ), экссудативный плеврит в фазе осумкования, кавернозный туберкулез и казеозная пневмония - по 3,6 \%.
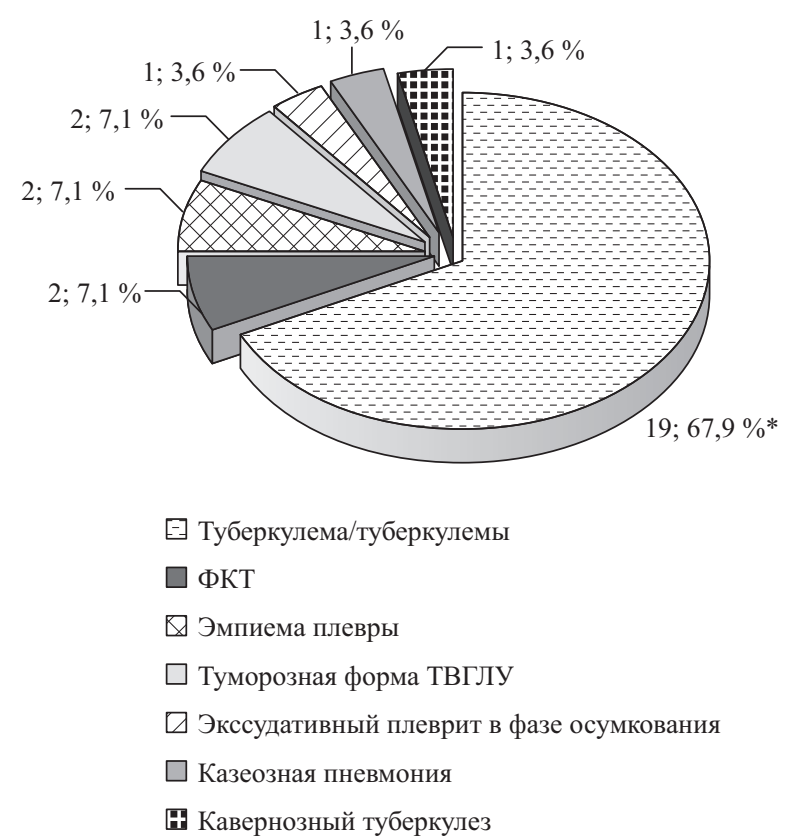

Структура клинических форм туберкулеза на момент операции * из них с распадом - $6(21,4 \%)$ 
Таблица 1. Объем и виды оперативного вмешательства

\begin{tabular}{|l|c|c|}
\hline \multicolumn{1}{|c|}{ Объем и вид операции } & Абс. число & Доля (\%) \\
\hline Краевая резекция 1 сегмента & 6 & 21,4 \\
\hline Комбинированная резекция 3-4 сегментов (в том числе 1 с лимфодиссекцией 3 групп с ВГЛУ) & $5(1)$ & $17,9(3,6)$ \\
\hline Краевая резекция 2 сегментов & 4 & 14,3 \\
\hline Анатомическая резекция 2 сегментов & 3 & 10,7 \\
\hline Плеврэктомия & 3 & 10,7 \\
\hline Лобэктомия & 2 & 7,1 \\
\hline Анатомическая резекция 1 сегмента & 2 & 7,1 \\
\hline Плевропульмонэктомия & 2 & 7,1 \\
\hline Лимфодиссекция 3 групп с ВГЛУ & 1 & 3,6 \\
\hline ВСЕГО & 28 & 100 \\
\hline
\end{tabular}

Примечание. ВГЛУ - туберкулез внутригрудных лимфатических узлов.

Всем пациентам на разных сроках химиотерапии проведены оперативные вмешательства различного объема (табл. 1). Операции выполнены в плановом порядке, на момент их проведения признаки лабораторной (в гемограмме: ускоренная СОЭ, лейкоцитоз, сдвиг лейкоцитарной формулы влево) и рентгенологической активности воспалительного процесса отсутствовали.

Из табл. 1 видно, что наиболее часто выполнялись краевые резекции легких в объеме до 2 сегментов в 35,7 \% случаев, комбинированные резекции легких в 17,9\% и анатомические резекции до 2 сегментов в $17,8 \%$.

Кровь для исследования уровня САА и СРБ брали до оперативного вмешательства, через неделю после операции и далее - ежемесячно до завершения основного курса XТ. Оценку уровня маркеров острой фазы воспаления определяли методом иммуноферментного анализа в плазме с К ЭДТА, полученной центрифугированием образцов периферической крови исследуемых больных.

CAA определяли с помощью набора SEA885Hu (Cloud-Clone Corp., США), согласно инструкции изготовителя. Диапазон определения тест-системы - 1,56100 нг/мл, минимальная определяемая концентрация 0,66 нг/мл. Образцы плазмы предварительно разводили $1: 100$ с помощью раствора для разведения. Полученные результаты выражали в мкг/мл.

СРБ тестировали с помощью набора реагентов для высокочувствительного иммуноферментного определения СРБ-ИФА («Вектор Бест», Российская Федерация). Диапазон определения: 0,1-200 МЕ/л, чувствительность - 0,05 MЕ/л. Образцы плазмы предварительно разводили $1: 100$ с помощью раствора для разведения. Полученные показатели пересчитывали в мг/л с использованием коэффициента пересчета 1,020.

Все пациенты находились под наблюдением фтизиатра и хирурга. Через 14 дней после операции выполняли обзорную рентгенограмму органов грудной клетки в двух проекциях (прямой и боковой на стороне операции) для оценки расправления оперированного легкого и мониторинга развития реактивного плеврита. При рентгенологических признаках плеврита и в случаях наличии жалоб на боль в грудной клетке проводили ультразвуковое исследование (УЗИ) плевральной полости для оценки объема экссудата.

Компьютерную томографию органов грудной клетки (КТ ОГК) проводили на различных сроках после операции:

- при объеме операции менее 2 сегментов, отсутствии у пациента симптомов обострения заболевания или осложнений КТ ОГК проводили через 2 мес после операции;

- при операциях большого объема (более 2 сегментов), комбинированных резекциях более 3 сегментов и плевропульмонэктомии - через 1 мес после оперативного вмешательства с целью контроля расправления оперированного легкого и формирования фиброторакса; в последующем - каждые 2 мес до завершения основного курса ХT.

Статистическую обработку материала проводили c помощью программы Microsoft Excel. Для каждой группы вычисляли среднее арифметическое (M), ошибку среднего $(m)$ и доверительный интервал (ДИ). Сравнение групповых средних проводили с помощью критерия Стьюдента. Статистическая значимость считалась достигнутой при $p<0,05$.

\section{Результаты}

С целью изучения влияния травмы легочной ткани при оперативном вмешательстве на показатели маркеров острой фазы воспаления пациенты были разделены на 2 группы. В 1-й группе $(n=15)$ объем оперативного вмешательства составил 1-2 сегмента легочной ткани, во 2-й группе $(n=13)$ - более 2 сегментов (табл. 2$)$.

Изучение показателей сывороточного амилоида А и СРБ в исследованных группах не выявило статистически значимых различий в зависимости от объема оперативного вмешательства до операции и через 1 нед после оперативного вмешательства.

С целью изучения прогностического значения (послеоперационные осложнения, прогрессирование туберкулезного процесса) повышения показателей маркеров острой фазы воспаления были сформированы 2 группы. В 1-ю группу включены 22 больных (без послеоперационных осложнений и прогрессирования тубер- 
Таблица 2. Показатели маркеров острой фазы воспаления до операции и через неделю после операции в зависимости от объема оперативного вмешательства

\begin{tabular}{|c|c|c|c|c|}
\hline \multirow[t]{2}{*}{$\begin{array}{l}\text { Маркеры острой } \\
\text { фазы воспаления }\end{array}$} & \multicolumn{2}{|c|}{$\begin{array}{c}\text { Объем операции 1-2 сегмента } \\
(n=15)\end{array}$} & \multicolumn{2}{|c|}{$\begin{array}{c}\text { Объем операции более } 2 \text { сегментов } \\
(n=13)\end{array}$} \\
\hline & перед операцией & $\begin{array}{c}\text { через } 1 \text { нед } \\
\text { после операции }\end{array}$ & перед операцией & $\begin{array}{c}\text { через } 1 \text { нед } \\
\text { после операции }\end{array}$ \\
\hline $\begin{array}{l}\text { Сывороточный ами- } \\
\text { лоид А (мкг/мл) }\end{array}$ & $\begin{array}{l}12,58 \pm 0,9 \\
\text { ДИ } \pm 1,76\end{array}$ & $\begin{array}{l}11,90 \pm 0,3 \\
\text { ДИ } \pm 0,59\end{array}$ & $\begin{array}{c}14,28 \pm 0,49 \\
\text { ДИ } \pm 0,96\end{array}$ & $\begin{array}{c}14,36 \pm 0,55 \\
\text { ДИ } \pm 1,07\end{array}$ \\
\hline $\begin{array}{l}\text { С-реактивный белок } \\
\text { (мГ/л) }\end{array}$ & $\begin{array}{c}12,45 \pm 1,13 \\
\text { ДИ } \pm 2,21\end{array}$ & $\begin{array}{l}16,1 \pm 2,2 \\
Д И \pm 4,31\end{array}$ & $\begin{array}{l}13,9 \pm 0,9 \\
\text { ДИ } \pm 1,76\end{array}$ & $\begin{array}{c}17,1 \pm 2,17 \\
\text { ДИ } \pm 4,25\end{array}$ \\
\hline
\end{tabular}

Примечание. Здесь и в табл. 3: ДИ-доверительный интервал.

кулеза), во 2-ю группу - 6 больных (послеоперационные осложнения - 4, прогрессирование туберкулезного процесса - 2). У 4 больных с осложнением отмечено развитие плеврита объемом от 50 до 120 мл.

Изучение уровня и динамики САА в 1-й группе показало, что его уровень до оперативного вмешательства составлял 13,11 $\pm 0,63$ мкг/мл. Во 2-й группе этот показатель составил $14,86 \pm 0,72$ мкг/мл, что статистически не отличалось от соответствующего значения в 1-й группе (табл. 3).

Через 1 нед и через 1 мес после операции в 1-й группе уровень САА был достоверно ниже, чем во 2-й группе $(12,3 \pm 0,57$ мкг/мл и 15,2 $\pm 0,6$ мкг/мл; $p=0,001747$ и $13,57 \pm 0,46$ мкг/мл и $18,5 \pm 0,21$ мкг/мл; $p=0,0096$ соответственно). В последующие сроки наблюдения показатели в группах колебались незначительно и не имели статистически достоверных различий.

Уровень СРБ до оперативного вмешательства статистически не различался в исследуемых группах и находился в 1-й группе на уровне $10,3 \pm 1,4$ мг/л и во 2-й группе 14,85 $\pm 2,17$ мг/л (табл. 4).

Во 2-й группе по сравнению с 1-й группой через 1 нед и через 1 мес после операции отмечен достоверный подъем уровня СРБ $(18,8 \pm 0,76$ мг/л и $14,75 \pm$ 1,4 мг/л; $p=0,017581$ и $18,6 \pm 1,1$ мг/мл и $12,8 \pm$ 1,73 мг/мл; $p=0,009067$ соответственно).

Таким образом, повышение уровней САА и СРБ после операции свидетельствует о развитии воспаления и требует дополнительных исследований с целью выявления послеоперационных осложнений или обострения туберкулеза. Последующий анализ показал, что у 4 пациентов с послеоперационными плевритами во всех случаях подъем САА и СРБ предшествовал выявлению экссудата в плевральной полости, по данным УЗИ. Развитие осложнений было диагностировано, по данным УЗИ плевральной полости, в 1 случае через 2 нед после операции, в 3 - через 1 мес. При этом во всех случаях не наблюдалось клинической картины развившихся осложнений в виде болей в грудной клетке. Следует отметить, что показатели, отражающие воспалительные изменения, в гемограмме также отсутствовали. Обострение специфического процесса было отмечено в 2 случаях. В обоих случаях обострение выявлено по результатам КТ ОГК. У 1 пациента через 1 мес после операции, по данным КТ ОГК, проведенного досрочно, учитывая большой объем операции (комбинированная резекция), отмечено появление фокуса инфильтрации с нечеткими контурами в оперированном легком. В другом случае при плановом контроле КТ ОГК через 2 мес после операции выявлен инфильтрат с полостью распада до 3 мм в диаметре. Коррекция химиотерапии позволила достичь положительной рентгенологической динамики: в одном случае через 4 мес после операции отмечено полное рассасывание инфильтрации, в другом - через 2 мес после операции (через 1 мес после коррекции схемы химиотерапии) отмечено закрытие полости распада.

\section{Обсуждение}

На настоящий момент основная масса работ в области иммунологии туберкулезной инфекции сосредоточена на двух основных направлениях, которыми являются поиск критериев иммунологической диагностики латентной стадии ее течения и активности различных форм

Таблица 3. Показатели сывороточного амилоида А (мкг/мл) до и после операции в зависимости от наличия послеоперационных осложнений или прогрессирования туберкулезного процесса

\begin{tabular}{|c|c|c|}
\hline $\begin{array}{c}\text { Срок исследо- } \\
\text { вания }\end{array}$ & $\begin{array}{c}\text { 1-я группа } \\
(n=22)\end{array}$ & $\begin{array}{c}\text { 2-я группа } \\
(n=6)\end{array}$ \\
\hline До операции & $\begin{array}{c}13,11 \pm 0,63 \\
\text { ДИ } \pm 1,23\end{array}$ & $\begin{array}{c}14,86 \pm 0,72 \\
\text { ДИ } \pm 1,41\end{array}$ \\
\hline \multicolumn{3}{|l|}{ После операции } \\
\hline 1 нед & $\begin{array}{c}12,3 \pm 0,57 \\
\text { ДИ } \pm 1,1\end{array}$ & $\begin{array}{l}15,2 \pm 0,6^{*} \\
\text { ДИ } \pm 1,17\end{array}$ \\
\hline $1 \mathrm{мес}$ & $\begin{array}{c}13,57 \pm 0,46 \\
\text { ДИ } \pm 0,9\end{array}$ & $\begin{array}{c}18,5 \pm 0,21^{* *} \\
\text { ДИ } \pm 0,41\end{array}$ \\
\hline 2 мес & $\begin{array}{c}13,28 \pm 0,51 \\
\text { ДИ } \pm 0,99\end{array}$ & $\begin{array}{c}17,71 \pm 2,1 \\
\text { ДИ } \pm 4,1\end{array}$ \\
\hline $3 \mathrm{мес}$ & $\begin{array}{l}14,6 \pm 1,1 \\
Д И \pm 2,15\end{array}$ & $\begin{array}{l}14,25 \pm 1,2 \\
Д И \pm 2,35\end{array}$ \\
\hline $4 \mathrm{мес}$ & $\begin{array}{l}13,2 \pm 0,65 \\
Д И \pm 1,27\end{array}$ & $\begin{array}{c}14,63 \pm 0,52 \\
\text { ДИ } \pm 1,01\end{array}$ \\
\hline $5 \mathrm{мес}$ & $\begin{array}{l}13,8 \pm 1,1 \\
Д И \pm 2,15 \\
\end{array}$ & $\begin{array}{c}15,05 \pm 0,52 \\
Д И \pm 1,01\end{array}$ \\
\hline $6 \mathrm{мес}$ & $\begin{array}{l}14,9 \pm 1,1 \\
Д И \pm 2,15\end{array}$ & $\begin{array}{l}15,6 \pm 0,83 \\
\text { ДИ } \pm 1,62\end{array}$ \\
\hline
\end{tabular}

Примечание. *-p ${ }^{*}$ 0,001747; **-p $=0,0001$. 
Таблица 4. Показатели С-реактивного белка плазмы крови (мг/л) до и после оперативного лечения в сравниваемых группах

\begin{tabular}{|c|c|c|}
\hline $\begin{array}{c}\text { Срок } \\
\text { исследования }\end{array}$ & $\begin{array}{c}\text { 1-я группа } \\
(n=22)\end{array}$ & $\begin{array}{c}2 \text { 2-я группа } \\
(n=6)\end{array}$ \\
\hline До операции & $\begin{array}{l}10,3 \pm 1,4 \\
\text { ДИ } \pm 2,74\end{array}$ & $\begin{array}{c}14,85 \pm 2,17 \\
\text { ДИ } \pm 4,25\end{array}$ \\
\hline \multicolumn{3}{|l|}{ После операции } \\
\hline 1 нед & $\begin{array}{c}14,75 \pm 1,4 \\
\text { ДИ } \pm 2,74\end{array}$ & $\begin{array}{c}18,8 \pm 0,76 * \\
\text { ДИ } \pm 1,49\end{array}$ \\
\hline $1 \mathrm{мec}$ & $\begin{array}{c}12,8 \pm 1,73 \\
Д И \pm 3,4\end{array}$ & $\begin{array}{c}18,6 \pm 1,1 * * \\
\text { ДИ } \pm 2,16\end{array}$ \\
\hline 2 мес & $\begin{array}{c}10,36 \pm 1,75 \\
\text { ДИ } \pm 3,43\end{array}$ & $\begin{array}{c}14,83 \pm 2,63 \\
\text { ДИ } \pm 4,62\end{array}$ \\
\hline $3 \mathrm{мес}$ & $\begin{array}{l}4,4 \pm 0,83 \\
\text { ДИ } \pm 1,63\end{array}$ & $\begin{array}{c}11,14 \pm 2,84 \\
\text { ДИ } \pm 5,57\end{array}$ \\
\hline 4 мес & $\begin{array}{c}7,9 \pm 1,8 \\
Д И \pm 3,53\end{array}$ & $\begin{array}{c}9,56 \pm 3,38 \\
\text { ДИ } \pm 6,62\end{array}$ \\
\hline $5 \mathrm{мес}$ & $\begin{array}{c}7,5 \pm 1,5 \\
Д И \pm 2,94\end{array}$ & $\begin{array}{l}10,3 \pm 3,25 \\
\text { ДИ } \pm 6,37\end{array}$ \\
\hline $6 \mathrm{мес}$ & $\begin{array}{l}5,1 \pm 1,28 \\
\text { ДИ } \pm 2,51\end{array}$ & $\begin{array}{l}10,53 \pm 2,7 \\
\text { ДИ } \pm 5,29\end{array}$ \\
\hline
\end{tabular}

Примечание. ${ }^{*}-p=0,017581 ; * *-p=0,009067$

туберкулеза [12]. Исследования, посвященные прогнозированию риска обострения туберкулезного процесса после оперативного вмешательства, единичные и касаются взрослого контингента больных. А.В. Елькин и соавт. [13] представили данные о развитии обострения специфического процесса в виде эмпиемы плевры у 37 \% больных, оперированных по поводу фибрознокавернозного туберкулеза. Прогностическими неблагоприятными критериями стали совокупность и определенный уровень до операции ряда биохимических показателей (аденозиндезаминаза-1, сывороточный альбумин, $\alpha_{2}$-макроглобулин и ингибитор $\alpha_{1}$-протеазы) [13].

Роль белков острой фазы воспаления (СРБ и САА) при туберкулезе исследовали в основном для контроля эффективности лечения. M.A. De Groote и соавт. (2013) использовали высокоспецифичную мультиплексную платформу определения большого числа белков в сыворотке 39 больных с активной формой туберкулеза. Мониторинг белковых показателей проводили до начала и через 8 нед специфической терапии. Было показано, что СРБ, САА, гаптоглобин и ингибитор $\alpha_{1}$-протеазы снижались к 8-й неделе практически у всех больных. Активность туберкулезного процесса (бактериовыделение, наличие полостей распада) выражалась в более высоких показателях СРБ и САА лишь у половины исследованных больных [14]. Исследования уровней СРБ и САА у детей и подростков, больных туберкулезом, дают более противоречивые результаты [15], и значимость этих маркеров для прогнозирования послеоперационных осложнений и обострения туберкулезного процесса после хирургического вмешательства ранее не изучались. Вместе с тем новые данные о структуре и функции СРБ и САА и современные методы их определения с помощью высокочувствительных тестсистем могут значительно расширить диагностические и прогностические возможности данных маркеров $[6,9]$.

\section{Выводы}

1. Объем операции, выполненной в плановом порядке по поводу туберкулеза органов дыхания, не влияет на уровни САА и СРБ через 1 нед после оперативного вмешательства.

2. Одновременное повышение уровней СРБ и САА на ранних сроках после операции (1 нед, 1 мес) свидетельствует о развитии воспалительного процесса и служит прогностическим критерием послеоперационного осложнения (экссудативный плеврит) или обострения туберкулезного процесса.

\section{Вклад авторов}

Концепция и дизайн исследования - Овсянкина Е.С., Панова Л.В.; сбор и обработка материала Хитева А.Ю., Авербах М.М.; статистическая обработка - Авербах М.М.; написание текста - Хитева А.Ю.; редактирование - Панова Л.В.

\section{- Литература}

1. Основные показатели по туберкулезу в Российской Федерации за 2018 г. Федеральный Центр мониторинга противодействия распространению туберкулеза в Российской Федерации ФГБУ «ЦНИИОИЗ» Минздрава России. URL: https://mednet.ru/ images/materials/CMT/2019_god_tuberkulez_deti.pdf

2. Овсянкина Е.С., Эргешов А.Э., Губкина М.Ф., Панова Л.В., Юхименко Н.В. Научные достижения и перспективы научных исследований детско-подросткового отдела ФГБНУ «ЦНИИТ» (к 100-летию детско-подростковой клиники ФГБНУ «ЦНИИТ»). Вестник ЦНИИТ. 2019; (3): 5-12. DOI: https://doi.org/10.7868/ S2587667819030014

3. Черешнев В.А., Гусев Е.Ю. Иммунологические и патофизиологические механизмы системного воспаления. Медицинская иммунология. 2012; 14 (1-2): 9-20. DOI: https://doi.org/ 10.15789/1563-0625-2012-1-2-9-20

4. Авербах М.М., Гергерт В.Я. Иммунитет при туберкулезе В кн.: Туберкулез органов дыхания у детей и подростков: руководство для врачей. Эргешов А.Э., Овсянкина Е.С., Губкина М.Ф. (ред.). Москва, 2019: 524 с.
5. Алинежад C.М., Будник О.А., Таганович А.Д. Динамика изменения концентрации С-реактивного белка и активности аденозиндезаминазы при туберкулезном плеврите и их дифференциально-диагностическая ценность. Медицинский журнал. 2008; (2): 21-5. URL: http://rep.bsmu.by/handle/BSMU/3290

6. Brown J., Clark K., Smith K. et al. Variation in C - reactive protein response according to host and mycobacterial characteristics in active tuberculosis. BMC Infect. Dis. 2016; (16): 265. DOI: https:// doi.org/10.1186/s12879-016-1612-1

7. Jayaraman S., Haupt C., Gurs O. Paradoxical effects of serum amyloid a on the lipoprotein oxidation suggest a new antioxidant function for SAA. Jю Lipid Res. 2016; 57 (12): 2138-49. DOI: https://doi. org/10.1194/jlr.M07119157

8. Shah C., Hari-Dass R., Raynes J.G. Serum amyloid A is an innate immune opsonin for Gram-negative bacteria. Blood. 2006; 108 (5): 1751-7. DOI: https://doi.org/10.1182/blood-2005-11-011932

9. Ye R.D., Sun L. Emerging functions of serum amyloid A in inflammation. J. Leukoc. Biol. 2015; 98 (6): 923-9. DOI: https://doi.org/ 10.1189/jlb.3VMR0315-080R 
10. De Beer F.C., Nel A.E., Qie R.P. et al. Serum amyloid A protein and C-reactive protein levels in pulmonary tuberculosis: relationship to amyloidosis. Thorax. 1984; 39 (3): 196-200. DOI: https://doi.org/ 10.1136/thx.39.3.196.84

11. Каминская Г.О., Абдулаев Р.Ю., Комиссарова О.Г. Сывороточный амилоидный белок А у больных туберкулезом легких. Туберкулез и болезни легких. 2012; (5): 27-32.

12. Владимирский М.А. Иммунологические методы диагностики туберкулёзной инфекции у детей и подростков. проблемы и перспективы. Иммунология. 2018; 39 (1): 61-6. DOI: http://doi.org/ 10.18821/0206-4952-2018-39-1-61-66
13. Елькин А.В., Титаренко О.Т., Эсмельдяева Д.С., Дьякова М.Е., Алексеева Н.П., Перова Т.Л. Оценка риска послеоперационных инфекционных осложнений у больных фиброзно-кавернозным туберкулезом легких. Туберкулез и болезни легких. 2009; 86 (5): 31-4.

14. De Groote M.A., Nahid P., Jarlsberg L. et al. Elucidating novel serum biomarkers associated with pulmonary tuberculosis treatment. PLoS One. 2013. Vol. 8, N 4. Article ID e61002. DOI: http://doi. org/10.1371/journal.pone.0061002

15. Kumar N.P, Anuradha R., Andrade B.B. et al. Circulating biomarkers of pulmonary and extrapulmonary tuberculosis in children Clin. Vaccine Immunol. 2013; 20 (5): 704-11. DOI: http://doi.org/ 10.1128/CVI.00038-13

\section{- References}

1. The main indicators for tuberculosis in the Russian Federation for 2018 are the Federal Center for Monitoring the Response to the Spread of Tuberculosis in the Russian Federation FSBI TsNIIOISE of the Ministry of Health of Russia. URL: https://mednet.ru/images/ materials/CMT/2019_god_tuberkulez_deti.pdf (in Russian)

2. Ovsyankina E.S., Ergeshov A.E., Gubkina M.F., et al. Scientific achievements and prospects of scientific research of the children's and adolescents', CTRI (dedicated to the 100th anniversary of the children's and adolescents' clinic, CTRI). Vestnik TsNIIT. 2019; (3): 5-12. DOI: https://doi.org/10.7868/S2587667819030014 (in Russian)

3. Chereshnev V.A., Gusev E.Yu. Immunological and pathophysiological mechanisms of systemic inflammation. Meditsinskaya immunologiya. 2012; 14 (1-2): 9-20. DOI: https://doi.org/10.15789/15630625-2012-1-2-9-20 (in Russian)

4. Averbakh M.M., Gergert V.Ya. Immunity in tuberculosis. In Ergeshov A.E., Ovsyankina E.S., Gubkina M.F. (eds). Respiratory Tuberculosis in Children and Adolescents. A guide for doctors. Moscow, 2019: 524 p. (in Russian)

5. Alinezhad S.M., Budnik O.A., Taganovich A.D. Dynamics of change of C-reactive protein concentration and adenosine dezaminase activity in tuberculosis pleurisy and their differential diagnostic value. Meditsinskiy zhurnal. 2008; (2): 21-5. URL: http://rep.bsmu. by/handle/BSMU/3290 (in Russian)

6. Brown J., Clark K., Smith K., et al. Variation in C - reactive protein response according to host and mycobacterial characteristics in active tuberculosis. BMC Infect. Dis. 2016; (16): 265. DOI: https:// doi.org/10.1186/s12879-016-1612-1

7. Jayaraman S., Haupt C., Gurs O. Paradoxical effects of serum amyloid a on the lipoprotein oxidation suggest a new antioxidant function for SAA. J. Lipid Res. 2016; 57 (12): 2138-49. DOI: https://doi.org/ 10.1194/jlr.M07119157

\section{Сведения об авторах}

Авербах Михаил Михайлович - д.м.н., проф., главный научный сотрудник отдела иммунологии ФГБНУ «ЦНИИТ Минобрнауки России, Москва, Российская Федерация; e-mail: amm50@mail.ru, http://orcid.org/ 0000-0001-7706-3841

Панова Людмила Владимировна - д.м.н., ведущий научный сотрудник детско-подросткового отдела ФГБНУ «ЦНИИТ» Минобрнауки России, Москва, Российская Федерация; e-mail: detstvocniit@mail.ru, http://orcid.org/0000-0003-2417-8295

Овсянкина Елена Сергеевна - д.м.н., проф., руководитель детско-подросткового отдела ФГБНУ «ЦНИИТ» Минобрнауки России, Москва, Российская Федерация; e-mail: detstvocniit@mail.ru, http://orcid.org/0000-0002-0460-7585

Хитева Антонина Юрьевна - м.н.с. детско-подросткового отдела ФГБНУ «ЦНИИТ» Минобрнауки России, Москва, Российская Федерация; e-mail: detstvocniit@mail.ru, http://orcid.org/00000003-3664-1750
8. Shah C., Hari-Dass R., Raynes J.G. Serum amyloid A is an innate immune opsonin for Gram-negative bacteria. Blood. 2006; 108 (5): 1751-7. DOI: https://doi.org/10.1182/blood-2005-11-011932

9. Ye R.D., Sun L. Emerging functions of serum amyloid A in inflammation. J. Leukoc. Biol. 2015; 98 (6): 923-9. DOI: https://doi.org/ 10.1189/jlb.3VMR0315-080R

10. De Beer F.C., Nel A.E., Qie R.P., et al. Serum amyloid A protein and C-reactive protein levels in pulmonary tuberculosis: relationship to amyloidosis. Thorax. 1984; 39 (3): 196-200. DOI: https://doi.org/ 10.1136/thx.39.3.196.84

11. Kaminskaya G.O., Abdulaev R.Yu., Komissarova O.G. Serum amyloid protein A in patients with pulmonary tuberculosis. Tuberkulez i bolezni legkikh. 2012; (5): 27-32. (in Russian)

12. Vladimirsky M.A. Immunological methods for Tb infection diagnostics in children and adolescents. Challenges and opportunities Immunologiya. 2018; 39 (1): 61-6. DOI: http://doi.org/10.18821/02064952-2018-39-1-61-66 (in Russian)

13. ElkinA.V., Titarenko O.T., Esmel'dyaeva D.S., D’yakova M.E., Alekseeva N.P., Perova T.L. Assessment of the risk of postoperative infectious complications in patients with fibrous-cavernous pulmonary tuberculosis. Tuberkulez i bolezni legkikh. 2009; 86 (5): 31-4 (in Russian)

14. De Groote M.A., Nahid P., Jarlsberg L., et al. Elucidating novel serum biomarkers associated with pulmonary tuberculosis treatment. PLoS One. 2013; 8 (4): e61002. DOI: http://doi.org/10.1371/ journal.pone.0061002

15. Kumar N.P, Anuradha R., Andrade B.B., et al. Circulating biomarkers of pulmonary and extrapulmonary tuberculosis in children. Clin. Vaccine Immunol. 2013; 20 (5): 704-11. DOI: http://doi.org/ 10.1128/CVI.00038-13

\section{Authors' information}

Mikhail M. Averbakh - MD, Prof., Principal Researcher of Immunology Department, CTRI of the MSHE of Russia, Moscow, Russian Federation; e-mail: amm50@mail.ru, http://orcid.org/0000-00017706-3841

Lyudmila V. Panova - MD, Leader Researcher of Child and Adolescent Department, CTRI of the MSHE of Russia, Moscow, Russian Federation; e-mail: detstvocniit@mail.ru, http://orcid.org/0000-00032417-8295

Elena S. Ovsyankina - MD, Prof., Head of Child and Adolescent Department, CTRI of the MSHE of Russia, Moscow, Russian Federation; e-mail: detstvocniit@mail.ru, http://orcid.org/0000-0002-04607585

Antonina Yu. Khiteva - Junior Researcher of Child and Adolescent Department, CTRI of the MSHE of Russia, Moscow, Russian Federation; e-mail: detstvocniit@mail.ru, http://orcid.org/0000-00033664-1750 